\title{
Zveřejnit či nechat skryté: Jak čtenáři Blesku zdůvodňují politickou relevanci informací o soukromí politikü ${ }^{1}$
}

\author{
Martin Volek ${ }^{2}$
}

\begin{abstract}
Publish or keep hidden: How readers of the tabloid Blesk discuss the public and private lives of politicians
Politicians as public persons are under increasing review by both the media and the general public. This review focuses not only on acts in public office, both official and unofficial, but also on the behavior of politicians in private life that could, in a real or imagined way, influence their performance in public office. This paper presents the perceptions of the boundaries between the public and private lives of politicians by readers of the most popular Czech tabloid, Blesk. The qualitative analysis based on in-depth interviews and a focus group with readers presents arguments that readers use to categorize information about politicians into that that belongs in the public domain and should be therefore published, and that that belongs to the private sphere and should not be published. In the readers' views, citizens have the right to know about a politician's private life, such as information that reflects a politician's character and about possible influences from their private life on their performance in public office. The readers also consider how it feels for a politician to be a private person in public office under public scrutiny. These readers then often advocate the right of a politician to have his privacy respected, since these readers themselves would not be pleased to be under such a bigh level of public scrutiny regarding their own lives. It seems that the readers' arguments are largely based on their personal history. We finally suggest that research on political participation would be enriched by including the perspective of everyday life experiences of the general public.
\end{abstract}

Keywords: Celebritization, Perception of Politics, Public and Private, Tabloids.

\section{1. Úvod}

Pro své politické rozhodování čerpá veřejnost většinu informací z masových médií. Ta přinášejí široké spektrum zpráv o politickém dění a jeho aktérech - jak informace o přijatých zákonech, veřejných vystoupeních, volebních programech a politických postojích, tak i o vnitropolitických vyjednáváních nebo prijímání úplatků, ale také informace o rodinách politiků, o trávení jejich volného času, osobních zálibách i prohřešcích. Všechna tato sdělení vstupují do politického rozhodování i přesto, že politickou relevanci některých z nich je možné zpochybňovat. Jsou třeba informace o rodinném životě politika politicky relevantní, a měly by být proto zveřejňovány, nebo spadají pod ochranu soukromého života a měly by být před zveřejněním chráněny?

V českém kontextu se mediálním zobrazením soukromí politiků zabývala Denisa Kasl Kollmanová (2012), která analyzovala zobrazení soukromé sféry politiků na stránkách deníků Blesk a MF Dnes. Identifikovala tři argumentační linie, kterými je ve článcích legitimizováno zobrazování soukromí politiků: investigativní linii, intimní linii a linii image. Investigativní linie zkoumá ekonomicko-politické vazby osob, s nimiž politiky pojí milostný vztah, a hledá neoprávněné výhody těchto osob plynoucí z politikova zneužití veřejné funkce. Intimní linie

\footnotetext{
1 Text vznikl v rámci projektů GAČR č. P404/11/2098 „Trend zrychlování sociální dynamiky: neurčitost, hierarchické/rovné struktury vládnutí a interiorizace historiî́ a GAUK č. 117010 „Co je na politicích „veřejné“? Český mediální obraz a čtenářská percepce politické funkce.“

${ }^{2}$ Kontakt na autora: Mgr. Martin Volek, PhD student, Institut sociologických studií Fakulty sociálních věd Univerzity Karlovy v Praze, U Kř́že 8, 15800 Praha 5. E-mail: mart.volek@gmail.com.
} 
prezentuje milostné vztahy politiků jako informace, které mají sloužit občanům k posouzení morálního profilu politika např́iklad $\mathrm{v}$ př́padě jeho nevěry. Linie image slouží $\mathrm{k}$ prostému zviditelňování politika a k budování jeho dobrého jména. Analýzou Blesku a MF Dnes se zabývala také Eliška Jungová (2006), která ukázala, jak je na stránkách těchto deníků konstruována veřejnost a její zájmy. MF Dnes vytváří obraz politické veřejnosti a následně vystupuje jako mluvčí a obránce jejích zájmů vưči politické reprezentaci. Oproti tomu Bleskem vytvořená veřejnost má znaky sousedské komunity sledující soukromé eskapády politiků spíše než politiku jako takovou.

Předkládaný text řeši otázku zveřejňování soukromé sféry politiků pohledem př́jemců masmediálních obsahů. Zaměřuje se na analýzu argumentů, kterými veřejnost kategorizuje informace ze soukromého a osobního života politiků na politicky relevantní a irelevantní. V širokém spektru př́jemců mediálních obsahů se soustředí na masového př́jemce. Pro jeho identifikaci je jakožto zprostředkující sociokulturní charakteristika použito čtenářství deníku Blesk, které bývá spojováno se znaky nekulturnosti a apolitičnosti (srov. Černý 2006: 1074; Marada 2002: 8). Čtenáŕi Blesku bývají chápáni jako ta část veřejnosti, která je protikladem vůči elitě. V tomto smyslu je možné je označit za zástupce masy (byt' toto označení může být zkratkovité či účelové, srov. Prokop 2005), což je podpořeno i tím, že Blesk je nejčtenějším deníkem v České republice.

Před vlastní prezentací výsledků analýzy jsou $\mathrm{v}$ tomto článku představena teoretická východiska, která samotné analýze předcházela. Po nich je uveden model veřejného a soukromého, který je nástrojem analýzy i jejím dílčím výsledkem. Nakonec jsou prezentovány výsledky analýzy $\mathrm{v}$ podobě klíčových argumentů, kterými čtenáři rozlišují veřejné a soukromé politiků.

\section{Vnímání politiky}

Dynamicky narůstající počet informací o politice, který je spojen s rozmachem nových médií, nevedl k výrazně vyšší politické informovanosti veřejnosti (srov. Carpini 1996; Lee, Deli Carpini 2010). Moderní technologie sice usnadnily lidem př́mý př́stup $\mathrm{k}$ informacím o politickém dění, nezvýšily však nutně zájem občanů o ně. V prostř̌edí narůstajícího počtu dostupných informací narážejí lidé na limity svých kognitivních kapacit a hledají zjednodušení a informační zkratky, které jim nabízejí masová média (srov. Farina 2010). Jednou z význačných informačních zkratek může být zaměření se na osobnosti politiků. Soupeření politických idejí, programů a návrhů řešení veřejných problémů je pak převáděno na úroveň osobních bojů jednotlivých politiků (srov. Galtung, Ruge 1965). Politika je tak prezentována jako osobní přiběhy jejích jednotlivých aktérů a čtenáŕi, diváci a posluchači se soustředí spíše na jednání politiků než přímo na politické události jako takové.

Politici nepůsobí pouze ve vlastní sféře politiky a ve světě mediálních zpráv, které jejich politické kroky představují veřejnosti. Žijí také své soukromé životy, které na jednu stranu mohou být politikou ovlivňovány, na druhou stranu mohou také politiku ovlivňovat a zároveň mohou být strategicky používány pro prezentaci politiků v masových médiích (Corner 2000). Počet a podíl informací o soukromém životě politiků se podle řady autorů zvyšuje a postupně vytlačuje jiné informace o politice. Možným následkem je posuzování politiků podle kritérií, která jsou politicky nepodstatná a typická pro celebrity zábavního průmyslu. Tradičnější pohled hodnotí tuto 
celebritizaci ${ }^{3}$ politiky negativně, nebot' média se přestávají věnovat politickým záležitostem jako takovým a soustředí se pouze na zábavnou stránku života politiků. Politici se stávají jedněmi z mnoha mediálních hvězd a zpravodajství ztrácí svou politickou relevanci (Boorstin 1992; Davis, Owen 1998; Farina 2010; Kuhn 2007; Langer 2007, 2010; Meyrowitz 2006; Postman 2010; Weiskel 2005; West, Orman 2003). Novější pohled naopak zdůrazňuje pozitivní př́nosy dưrazu na soukromý život politiků. Důraz na lidskou stránku príbližuje politiky a jejich rozhodnutí široké veřejnosti, pro kterou by jinak politika byla nepř́stupná a nesrozumitelná. Zobrazení politiků $\mathrm{v}$ běžných situacích může přinejmenším přilákat pozornost veřejnosti $\mathrm{k}$ politice a mít pozitivní vliv na politickou participaci. Neméně důležité je však to, že může zpřístupnit jazyk politiky jazyku běžných lidí, kteří interpretují politiku na základě své každodenní zkušenosti, jež je spojená s jejich profesním i rodinným životem, spíše než na základě oficiálních rámců produkovaných politickými profesionály (Lumby 1999; Macdonald 2000; Van Zoonen 1998, 2005; Walsh 2004; v rámci „soft news“ Baum 2002, 2003; Prior 2003).

Politici se v médiích objevují v širokém spektru situací veřejného i soukromého života. Často nejasné vymezení vztahu těchto informací $\mathrm{k}$ veřejné funkci dává divákưm a čtenářum možnost různého výkladu politického významu těchto informací. Při tomto výkladu vycházejí ze své životní zkušenosti a sociální identity (srov. Hall 1999; Walsh 2004), na základě kterých mohou různí lidé jednu a tu samou informaci o jednání politika interpretovat jako politicky relevantní i jako politicky irelevantní. Interpretaci mohou zároveň měnit v závislosti na kontextu situace.

\section{Dichotomie veřejného a soukromého}

Rozdělení na veřejné a soukromé je jednou z velkých dichotomií společenských věd i společnosti jako takové (Bobbio 1989; Bailey 2002: 15; Jenks 1998). Jako u každé velké dichotomie je možné v jejím rámci vysledovat různé a často i protikladné pokusy o její vymezení. Jeff Weintraub (1997) ve svém přehledu představuje čtyři tradice rozlišení veřejného a soukromého. První z nich je liberálně ekonomický model, který rozlišení mezi veřejným a soukromým zakládá na rozlišení státu na straně veřejného a tržní ekonomiky na straně soukromého. Druhou tradicí je klasický př́stup republikánské ctnosti, který veřejnou oblast definuje $\mathrm{v}$ pojmech politické komunity a soukromou oblast $\mathrm{v}$ pojmech občanství. Třetí tradicí je prŕstup sociální historie a antropologie, který staví do protikladu soukromou sféru, jakožto v domácnosti konstituované vztahy vzájemné náklonnosti, proti veřejné sfére jako oblasti sociability zprostředkované konvencemi, které umožňují různorodost a sociální odstup i přes fyzickou blízkost. Čtvrtou tradicí jsou tendence feministické analýzy, které pojímají rozdíl mezi soukromým a veřejným v termínech rozdílu mezi rodinou a ekonomickými vztahy $\mathrm{v}$ širší společnosti, které jsou genderově nevyvážené a pro ženy utlačující.

Velkou dichotomii veřejného a soukromého zakládá Norberto Bobbio (1989) na pojetí veřejného jako sféry politické moci a soukromého jako oblasti ležící mimo její dosah. Od této velké dichotomie odlišuje to, co nazývá druhým významem dichotomie veřejného a soukromého. V něm je sféra veřejného chápána jako oblast, která se odehrává před zraky veřejnosti, a je tak př́stupná jejímu přezkumu. Naopak sféra soukromého je očím veřejnosti skrytá. Velká dichotomie a druhý význam dichotomie veřejného a soukromého jsou odlišné a navzájem

\footnotetext{
${ }^{3}$ Pojem celebritizace politiky bývá používán také v druhém významu pro popis situace, kdy populární celebrity vstupující do politiky nebo ovlivňující politiku používají jako zdroj své politické kvalifikace obrazy ze své kariéry celebrity. Např́klad Arnold Schwarzenegger používal v průběhu své kandidatury do úřadu guvernéra obraz Terminátora, který byl jednou z jeho filmových rolí (srov. Drake, Higgins 2006; Street 2004, 2011; Weiskel 2005).
} 
nepřevoditelné přístupy. Otázka zveřejňování politické moci je odlišná od otázky po podstatě politické moci, nebot' politická moc zůstává politickou mocí, i když je přezkumu veřejnosti skrytá.

\section{Metodologie}

Empirická data pro tento text poskytlo 16 hloubkových rozhovorů a jedna skupinová diskuse (Focus Group) s pravidelnými čtenáŕi Blesku. Skupinová diskuse následovala pro prvních dvou hloubkových rozhovorech a účastnili se jí jiní respondenti než skupinových rozhovorů. Respondenti byli vybráni podle sociálně-demografického profilu čtenárù tohoto deníku s dodatečnou podmínkou věku nad 18 let a s tím spojeného volebního práva. Pravidelnost čtenářství Blesku byla definována jako čtení Blesku minimálně třikrát týdně a testována obeznámeností saktuálními tématy $\mathrm{v}$ něm obsaženými. ${ }^{4}$ Samotné rekrutování respondentů provedla na základě podrobného zadání komerční agentura.

Hloubkové rozhovory s muži vedl autor tohoto textu, rozhovory s ženami prováděla jeho kolegyně. ${ }^{5}$ Délka jednotlivých hloubkových rozhovorů byla přibližně od 30 do 100 minut. Pro vedení rozhovorů byly připraveny tematické okruhy. ${ }^{6}$ Zároveň však byla ponechána značná volnost pro možnost reakce na konkrétní výpovědi respondentů a pro doptávání se. Respondenti byli nejprve seznámeni s účelem rozhovoru a jeho pravidly. $\mathrm{V}$ úvodu rozhovoru byly otázky směřovány na respondentem aktuálně sledované události a na mediální chování. V jeho rámci byla pozornost soustředěna na důvod a způsob čtení Blesku a na jeho hodnocení, respondenti také srovnávali Blesk s dalšími deníky.7

Následující část rozhovoru se zaměřila na způsob, kterým respondenti vnímají mediální informace o politicích. Respondentům byly postupně předloženy tři články, které modelově zastupovaly tríi způsoby prezentace politiků v Blesku. První článek, „Vzal bývalý senátor úplatek? Korupce po letech u soudu“ (Blesk 2010b), se týkal pouze veřejného života, když informoval o soudu s Alexandrem Novákem obžalovaným z přijetí úplatku ve výši 40 mil. Kč v průběhu výkonu veřejné funkce. Druhý článek, „Topolánkova famílie v Toskánsku. Kde na to bere?“ (Blesk 2010a), se pohyboval na hranici veřejného a soukromého života, nebot' soukromou dovolenou bývalého premiéra Miroslava Topolánka propojoval s možnou korupcí v jeho veřejné funkci. Podle článku převyšovaly výdaje Miroslava Topolánka na dovolenou jeho př́jmy a zdůrazňoval jeho vazby na lobbistu Marka Dalíka. Třetí článek, „Paroubek: Ráno pláž, večer bazén... Exšéf ČSSD se vrátil z řecké pohádky do české ,pastoušky“““ (Blesk 2010c), zastupoval prezentaci ryze soukromého života politika, když informoval o dovolené bývalého premiéra Paroubka, aniž by tuto dovolenou explicitně vztahoval ke způsobu výkonu veřejné funkce jinak, že si Paroubek na dovolené odpočinul pro další politickou práci. Po přečtení článku se respondenti vyjadřovali $\mathrm{k}$ jeho obsahu a politické relevanci.

Třetí část rozhovoru se zaměřovala na to, jaké informace respondenti používají ve svém volebním chování k posouzení toho, zda je konkrétní politik vhodným kandidátem pro výkon

\footnotetext{
${ }^{4}$ Bližší informace o respondentech je možné nalézt v Př́loze 1.

${ }^{5}$ PhDr. Veronika Frantová - spoluřešitelka projektu GAUK č. 117010, v rámci kterého byly rozhovory realizovány.

${ }^{6}$ Scénáŕ rozhovorů je možné nalézt v Př́loze 2, byl použit pro hloubkové rozhovory i skupinový rozhovor.

${ }^{7}$ Pro žádného z respondentů nebyl Blesk jediným zdrojem informací o politickém a společenském dění (dalšími zdroji byla zejména televize, internet a rozhovory s kolegy, známými a členy rodiny). Většina respondentů měla také přehled o zpo̊sobu, kterým o politickém dění informují ostatní deníky, nicméně nepovažovali je za noviny vhodné pro ně.
} 
veřejné funkce. V závěru byl proveden pokus o nalezení normativního vymezení, které informace by $\mathrm{v}$ médiích měly a naopak neměly být zveřejňovány. Obdobnou strukturu měl i skupinový rozhovor.

V následujícím textu jsou uvedeny přímé citace výpovědí respondentů (ti jsou dále označeni jako čtenáři a ti, kteři rozhovory vedli, jako moderátoři).. Tyto výpovědi jsou zde vždy vytrženy z kontextu celého rozhovoru, který byl vzat v úvahu při analýze. ${ }^{8}$ Některé otázky tak mohou působit návodně, reagují však zpravila na respondentovy výpovědi z předchozích částí rozhovoru. Ačkoli respondenti byli pravidelnými čtenáŕi Blesku, zdálo se, že v průběhu řady rozhovorů se snažili od Blesku distancovat. Raději mluvili o jiných čtenářích Blesku, co jiní lidé rádi čtou v Blesku o politicích a jak jsou jiní lidé těmito informacemi ovlivňováni, než sami o sobě. Těmito jinými lidmi neměli na mysli nikoho konkrétního, ale spíše poukazovali na obecnou představu o chování lidí (generalizovaného druhého). W. Phillips Davison (1983) to nazývá efektem třetí osoby, kdy př́jemci masmediálních sdělení předpokládají, že tato sdělení mají větší vliv na ostatní lidi než na ně samotné.

Jiným důvodem odstupu od Blesku mohlo být, že si čtenáři byli vědomi určitého negativního obrazu spojeného se „čtením Blesku“, a bylo tak pro ně nepř́iemné se k tomu přiznat. Proto také mohli v průběhu rozhovoru usilovat o zpětnou racionalizaci svého čtení Blesku. Některé věci, které jsou Blesku obecně vyčítány, prezentovali jako jeho klady. Díky zkratkovitosti a povrchnosti informací v Blesku mohou být informování o všem důležitém, aniž by je to zatěžovalo. Díky zábavné formě podávání informací si při čtení Blesku mohou zároveň odpočinout a podobně. ${ }^{9}$

Předpokladem, který se v průběhu rozhovorů potvrdil, bylo, že veřejné a soukromé nejsou pojmy běžného jazyka čtenářů Blesku. Proto byly otázky na veřejné a soukromé pokládány nepřímo jako na to, co by média měla a co by naopak neměla zveřejňovat. V průběhu analýzy se ukázalo, že požadavek na to, co by „média zveřejňovat neměla“ může mít více významů: první z nich je politická irelevance - čtenáři si tuto informaci rádi přečtou, ale odmítají její kategorizaci jako politické informace. Druhým významem je odsouzení daného jednání jako něčeho špatného či čtenářům nepř́ijemného. S tím spojený požadavek na nezveřejňování zastupuje prání čtenářuo aby $\mathrm{k}$ tomuto jednání vůbec nedocházelo. A konečně třetím významem je právo politiků na to, aby tato informace nebyla zveřejňována, byt' by mohla být pro čtenáře atraktivní. Všechny tři významy byly v průběhu analýzy od sebe odlišovány.

Pro analýzu byl zvolen kombinovaný induktivně-deduktivní př́stup (inspirován Roberts 2002: 8-11; Thomas 2006), který byl rámován heuristickým př́stupem ke studiu sledovaných záležitostí (viz Kabele 2010). Všechny rozhovory byly nejdřive důkladně pročteny. Následně v nich byly v programu Atlas.ti zakódovány všechny oblasti, které se dle prvotního ohledání vztahovaly $\mathrm{k}$ výzkumnému tématu. Toto první kódováno bylo provedeno otevřenými kódy, které jsou odvozeny přímo z dat a mají podobu slov či sousloví prímo používaných respondenty. Po zakódování několika rozhovorů byly postupně přidávány také axiální kódy, které již mají analytickou podstatu. Jsou založeny na analýze otevřených kódů. Zatímco otevřené kódy slouží primárně pro popis a třídění dat, axiální kódy jsou nástrojem pro vlastní analýzu a slouží jako podklad pro interpretaci výsledků. Otevréné i axiální kódy jsou v průběhu práce průběžně přepracovávány. Spolu se zahrnováním dalších dat do analýzy je zpřesňováno jejich vymezení a

\footnotetext{
${ }^{8}$ Nicméně rozsah textu ji nedovoluje uvést ve větší délce nebo vysvětlit celý její kontext. Přepisy rozhovorů byly předány Sociologickému datovému archivu, kde jsou př́stupné odborné veřejnosti.

${ }^{9}$ Více $\mathrm{k}$ důvodům a způsobu čtení Blesku respondenty zmíněnými v tomto textu viz popularizační text Veroniky Frantové (2013).
} 
jsou uváděny do vzájemného vztahu. Vlastní zjištění pak byla tvořena z axiálních kódů, které byly opakovaně promýšleny, prohlubovány a reformulovány a postupně se stávaly výstupy analýzy.

Po zpracování čtyř rozhovorů vzniklo mnoho oblastí a analytických témat a byl hledán způsob, kterým další analytickou práci směřovat směrem. Průběžná zjištění byla propojena s teoretickým zázemím a byl navržen model dimenzí veřejného a soukromého v politice. Tento model vycházel z dichotomií veřejného a soukromého Norberta Bobbia a byl kompatibilní s již vytvořenými kódy. Byl ověřen jako vhodný nástroj další analýzy, tedy navazující redukce a interpretace kódů. V následující části je tento model stručně představen a jsou k němu uvedeny klíčové kódy s jejich charakteristikou.

\section{Model dimenzí veřejného a soukromého $v$ politice}

První dimenze modelu veřejného a soukromého v politice vychází z Bobbiovy velké dichotomie a je založena na přítomnosti a nepř́tomnosti politické moci. Veřejné v ní splývá s oblastí politiky a soukromé s oblastí mimo politiku. Druhá dimenze vychází z Bobbiova druhého významu dichotomie veřejného a soukromého a je jí viditelnost a skrytost ve smyslu veřejného jako př́stupného a soukromého jako nepř́stupného přezkumu veřejnosti.

$\mathrm{Na}$ rozdíl od Bobbiových dimenzí jsou dimenze $\mathrm{v}$ tomto modelu vnitřně propojeny. Dimenze politické moci konstituuje normativní nárok kladený na dimenzi viditelnosti, nebot' s politickou mocí je spojován požadavek na možnost jejího přezkumu ze strany veřejnosti nebo jejích zástupco̊. S oblastmi mimo politickou moc je spojováno právo na jejich skrytost ve smyslu ochrany před přezkumem každého. Na rozhodnutí politiků učiněných při výkonu veřejné funkce je kladen nárok na možnost veřejného přezkumu s výjimkou takových rozhodnutí, kde veřejný zájem vyžaduje jejich utajení. Oproti tomu osobní život běžných lidí je před veřejným přezkumem chráněn, nevyžaduje-li veřejný zájem jeho zveřejnění, jak je tomu typicky v př́padech trestných činů. Na vnitřní propojení mezi dimenzí politické moci a dimenzí viditelnosti je zároveň vázána dynamika ve smyslu vyjednávání mezi jednotlivými aktéry. Aktéŕi v oblasti politické moci, politici nebo státní úředníci, se často možnosti př́zkumu brání. Naopak aktéři mimo politickou moc, široká veřejnost či masová média jejím jménem, se možnosti přezkumu politické moci dožadují.

Kř́̌žení dimenze politické moci a dimenze viditelnosti vytváří čtyři oblasti (viz. Tabulka 1). První z nich je sféra politické moci, která se oficiálně odehrává před zraky veřejnosti. Je to idealizovaná oblast „pravé politiky“, v níž podle čtenářů probíhá konstruktivní politická činnost, jako např. schválení zákonů nebo věcná vystoupení politiků v Poslanecké sněmovně. Druhou oblastí je sféra politické moci, která je očím veřejnosti skryta, respektive je politiky skrývána před přezkumem veřejnosti, protože obsahuje zneužití politické moci v soukromý prospěch politiků „korupci a další výhody politikü“. Respondenti požadovali mediální zveřejňování tohoto zneužití a zároveň pro něj měli jakési pochopení, když připouštěli, že na místě politiků by pravděpodobně obdobně jednali také. Do této oblasti by také patřila kuloární vyjednávání a další prvky „reálné politiky“, ke které se čtenáři stavěli rezervovaně - na jednu stranu nejspíše chápali její nutnost, na druhou stranu se však nedokázali oprostit od nároků vyplývajících z idealizované představy o politice. Třetí oblastí je sféra mimo politickou moc, která je př́stupna očím veřejnosti. Je oblastí otevřeného nahlížení do soukromí. V této oblasti se se politici nejvíce blíží mediálním 
celebritám, ${ }^{10}$ nebot' právo na sledování soukromí bylo zdůvodňováno pouhou „,veřejnou známostí“. Politici také, stejně jako celebrity, mohou účelovým zveřejňováním informací ze svého rodinného života usilovat o zisk pozornosti a osobních sympatií. Informace ze soukromí však mohou podle respondentů být také důležitým indikátorem pro posuzování kompetence výkonu veřejné funkce, nebot' mohou přinášet dưležité informace o charakteru a osobnosti politiků. Respondenti zároveň kladli požadavek na reprezentativnost vzhledu a vystupování politiků i během soukromých aktivit. Čtvrtou oblastí je sféra mimo politickou moc, která podle respondentů je a má být skryta očím veřejnosti. Základním argumentem je zde popření výjimečného statusu výkonu veřejné funkce a důraz na srovnatelnost bytí politikem se zaměstnáním ostatních lidí - výkon veřejné funkce je „práce jako každá jiná“. Z toho vyplývá i požadavek na stejnou míru ochrany soukromí politiků jako běžných lidí, u kterých také není možné na základě dílčích informací o jednání v soukromém životě posuzovat jejich pracovní výkon nebo osobnostní charakter. Dochází k projekci čtenářů do postavení politiků skrze poukázání na nepř́ijemný pocit, když je na kohokoli z nich „vytáhnuto“ něco z jeho osobního života.

Tabulka 1: Model dimenzí veřejného a soukromého v politice

\begin{tabular}{|c|c|c|c|}
\hline & \multicolumn{2}{|c|}{ DIMENZE VIDITELNOSTI } \\
\hline & & Viditelné & Skryté \\
\hline \multirow{2}{*}{$\begin{array}{l}\text { DIMENZE } \\
\text { POLITICKÉ } \\
\text { MOCI }\end{array}$} & $\begin{array}{l}\text { Politická } \\
\text { moc }\end{array}$ & $\begin{array}{l}\text { Pravá politika (oficiální } \\
\text { vystoupení politiků, schválené } \\
\text { zákony) }\end{array}$ & $\begin{array}{l}\text { Korupce a výhody, reálná politika } \\
\text { (mělo by se zveřejňovat, já na } \\
\text { jejich místě bych také } \\
\text { zneužíval/a) }\end{array}$ \\
\hline & $\begin{array}{l}\text { Mimo } \\
\text { politickou } \\
\text { moc }\end{array}$ & $\begin{array}{l}\text { Verejná známost } \\
\text { prílákání } \\
\text { reprezelebrity, }\end{array}$ & $\begin{array}{l}\text { Práce jako každá jiná (soukromí } \\
\text { by se nemělo zveřejňovat, mně } \\
\text { na jejich místě by to také vadilo, } \\
\text { charakter se nedá poznat) }\end{array}$ \\
\hline
\end{tabular}

\section{Pravá politika}

Hranici mezi těmito čtyřmi oblastmi není snadné jednoznačně identifikovat. Jedna a ta samá informace mohla být $\mathrm{v}$ závislosti na svém kontextu a životní zkušenosti interpretována různým způsobem. Celá řada prŕípadů jednání v soukromém životě může mít vliv na aktuální či budoucí výkon veřejné funkce, na druhou stranu mohou mít politici i přes své postavení veřejných osob právo na ochranu svého soukromí. Jedna z oblastí však byla ve výpovědích čtenářu identifikována jednoznačně. Tato oblast přináleží do sféry politické moci a zároveň má být př́stupna přezkumu veřejnosti, tedy v terminologii rozhovorů je politikou a má být zveřejňována. $V$ průběhu analýzy byla tato oblast označena jako „pravá politika“.

Pravou politikou je možné vymezit jako oblast oficiálních politických aktů, u kterých čtenáři identifikují přímý vliv na svůj život. Tato oblast do značné míry splývá s idealizovaným obrazem politiky jako konstruktivní činnosti politických odborníků, jejichž veškeré jednání je zaměřeno ve prospěch zároveň konkrétních osob a společnosti jako celku, a proto není důvod, aby toto jednání bylo před zraky veřejnosti skryto. Pravou politikou jsou události, které jsou

\footnotetext{
${ }^{10}$ Celebrity ostatně dle rozhodnutí Nejvyššího soudu mají jakožto veřejně známé osoby nižší právo na ochranu soukromí (idnes.cz 2011).
} 
nezpochybnitelné, jednoznačné a pravdivé $\mathrm{v}$ tom smyslu, že $\mathrm{v}$ nich není prostor pro spekulace nebo možnosti alternativního výkladu. Informace o nich jsou stručné a často přinášejí návod pro správné jednání.

Moderátorka: „Kdybyste mèla prostě rozhodnout o tom, co se bude psát v Blesku o politice, co by tam bylo? A berte to üplné podle sebe."

Ctenárkea (7): „Mělo by tam bejt stručne a jednoduše napsaný to, co schválili a neschválili. Ihned. Ve chvili, kedy to schválej, tak by se to ihned mèlo napsat a présnost toho tréba dvouma vétama, présnost zákona. Ted'ko v̌̌ude, v novinách všude o tom, zmèna zákona o tý povinný výbavě aut. Oni o tom v̌sude v reklamě mlwvèj a nerekenou, že se to týká zimnich pneumatik bla bla bla."

Moderátorka: "Jasnè. A nevíte, co to żnamená, že co jako teda."

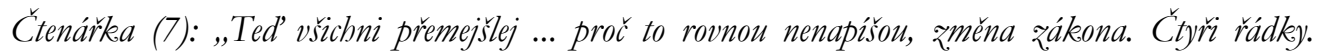
Vytiskly velkym pismenem. At’ to v'sichni vidèj, kedo se na to podivá, co je tam duiležity. At' ti lidi nemusej vyšilovat. Rychle sbirat informace, at' rovnou vidèj, hele reetla sem Bleske, je to napsaný ve dvou rádkách, sou to trì véci."

Moderátorka : "Jasně, rozumim."

Ćtenárka (7): „Proč to budou dlouze okecávat. Jednou oni to schválili, take ǔ̌ neni co okecávat. Je to schválený, hotovo. Musi to bejt. Sbohem. Pokuta taková a taková."

Je zjevné, že do pravé politiky nemají patřit osobní spory, hádky, osobní napadání nebo vulgarity. Zároveň se však zdá, že čtenáři odmítají i ve své podstatě politická vyjednávání týkající se řešení veřejných problémů. Jakoby předpokládali, že pro všechny veřejné problémy existuje jedno optimální řešení, které politici znají. Dlouhé diskuse o různých možnostech řešení politického problémů, které jsou často vedeny performativním způsobem snažícím se posluchače rétoricky přsesvědčit, jsou chápány jako zavádějící spory vedené osobními a soukromými motivy jednotlivých politiků - namísto toho, aby politici rychle nalezli optimální řešení (,jenom se hádajic").

Moderátor: „A co vy乏̌adujeme od Paroubka?"

Ċtenár (3): „Od Paroubka, aby, no jasně od politikư, aby délali zákony a aby prostě se tady dalo dobre žit, nebo slušně ̌̌it, a věci, který nepatréj mezi lidi, aby nebyly ani mezi politikama."

Moderátorka: „Povězzte ... o kom si préčrst, z.politiky, co by vás zajimalo ..."

Čtenárka (Focus Group, P): „O vládě nèco. Že oni rozhodujou ty zákony. Že vlastnè jsou v televiz̨i, tak. oni se tam jenom hádaji v Poslanecký snèmovně. Clověk kolikerát ani neví, o čem to je, ty zákony. "

\section{Zveřejňování soukromého: Korupce a výhody}

Slovo „korupce“ je pro čtenáře symbolickým zástupcem široké kategorie neefektivity politiky kvưli zneužití veřejné funkce pro soukromé účely. Korupce je vnímána jako neoprávněné přenesení politické moci a výhod s ní spojených do oblasti soukromého života. Toto přenesení moci se snaží politici skrýt, a je tak dvojím proviněním politiků - jak vlastním zneužitím veřejné moci, tak snahou toto zneužití utajit.

Jednoznačným zneužitím veřejné funkce je podle čtenářů takové jednání politiků, které je médii výslovně pojmenováno jako trestný čin. Zdá se, že tuto mediální kategorizaci chápou čtenáři jako fakt, který nemůže být diskutován a zpochybňován. K požadavku na zveřejnění korupčního jednání označeného jako trestný čin je možné nalézt paralelu v trestním právu. V kontextu trestného činu ztrácí pachatel právo na ochranu svého soukromí. Veřejnému přezkumu není zpř́stupněno pouze jeho jednání, ale také jeho osobnost, která má vysvětlit jeho motivace k protiprávnímu jednání. 
Pokud je na stránkách Blesku korupce jako „korupce“ nebo „přijetí úplatku“ jednoznačně pojmenována, je čtenáři Blesku chápána jako prokázaná. Je-li však přijetí úplatku pouze naznačeno a čtenářům je ponechán prostor pro vlastní interpretaci, zda k úplatku skutečně došlo, či nikoli, čtenáŕi zneužití veřejné funkce zpochybňují. To se ukázalo v odlišné reakci čtenářù na dva z článků z Blesku, které jim byly v průběhu rozhovoru předloženy. V článku „Vzal bývalý senátor úplatek? Korupce po letech u soudu“ (Blesk 2010b) je úplatek jednoznačně identifikován. Celý článek byl v Blesku zarámován politicky a čtenárí tak interpretovali jako informaci, která má být na stránkách Blesku zveřejněna.

Oproti tomu interpretace dalšího předloženého článku „Topolánkova famílie v Toskánsku. Kde na to bere?“ (Blesk 2010a) je pro čtenáře složitější. Informace ze soukromého života Topolánka jsou použity jako indikátor zneužití veřejné funkce. Na rozdíl od předchozího článku zde není úplatek př́mo pojmenován, ale je pouze naznačen jako možné vysvětlení zdroje financování nákladné dovolené. Článek není rámován jednoznačně politicky, nebot' Topolánek v článku figuruje spíše než jako politik jako osoba veřejně známá, která své nynější známosti dosáhla díky své bývalé politické funkci. Čtenáŕi často kladli důraz na absenci důkazu, který by měl prokazovat zneužití veřejné funkce. Jejich komentáře se spíše soustředily na vysoké př́ijmy politiků, díky kterým si tito mohou dovolit čtenářum nedostupnou luxusní dovolenou.

Ctenár (1): „Že si lidi rekenou kde na to berou. To je de facto tady, to je jestě transparentnèjš príklad. Protože tady je napsaný přmo, že pronajal vilu ten jeho kamarád že jo, nebo ten drubej politik, kolik to stálo peněz: I kedyž zase nemuižeme vèdét jestli je to pravda, jestli to tak je, nebo to tak neni, ale rozhodnè to

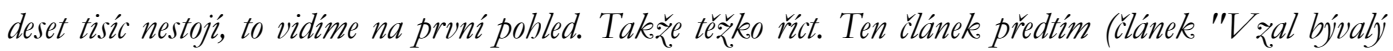
senátor úplatele? Korupce po letech u soudu.", pozn. autora) je lip napsanej než tenble, protože tadyten lidi ješté vic naštve, že de facto byl na takorýto dovoleny."

Moderátor: „Vás to naštvalo?"

Čtenár (1): „Mè naśtvalo, mè to poburùje, protože vadi mi, že utráci takovýble penize. Jestli je utrácí, já nevím, nebo mu někedo dá zadarmo takovejble výlet. Vice méně mè naštval. Já nemám rád ani Topolánka, ani Paroubka, to je jedna věc, ale Topolánka asi nemám rád ještě víc, protože mi prïjde strašně arogantni a nafoukanej. Takiže mnè to vadí."

Ctenárka (6): „Kde na to bere? Já si myslim, že na to má, aby tam jel. V̌̌dyt' jejich platy jsou dost vysoký na to, na to, aby si do tý Itálie zajel. Jasnè že kedyžje u Berlusconibo, tak je to trošku jiný. Ale i kdyby jel, desetkrát do roka... do Thajska. Tak s jeho príjmem určitè to neni problém."

Moderátor: "Jak se vám zdá tréba takovejble clánek?"

Čtenárka (6): „Určitě je to pravda, ̌̌e tam byl. Že ho tam fotèj. Ted’ sama uprímnè re reknète, co je na tom špatnýho, kdy žna dovolený von je do pưl těla? (komentár fotografie u clánku) Já vim, že je hroznej. Ale proč by mél mit sako a kravatu? Když je tam čtyricet stuprñu. A nebo že ji (Lucii Talmanovou) tady vyfotèj. To jsem rïkala, že ten život prostě oni nemaj jednoduchej. Takže má tady vystř̌enej zadek. Dyt’ má dovolenou! Je žisisimarjä."

Moderátorka: "Takovouble zprávu byste si prèéetla?"

Ctenárka (6): „Ale jo, určitě. U tobo obèda já si to prèrtu, pak rekenu no jo, no tak má se líp než my."

Vedle přímého finančního úplatku mohou politici zneužít či využít svou politickou moc pro získání řady „výhod“ ve svém soukromém životě. Podle čtenářu mají politici větší možnosti zařídit si lepší zacházení či služby než běžní lidé. Tyto lepší možnosti jsou dokládány velkým množstvím různých příběhů o těchto výhodách politiků. Tyto příběhy však čtenárí ve svých výpovědích pouze naznačují. Vyhýbají se vyprávění těchto př́iběhů a jejich hodnocení. 


\begin{abstract}
Moderátor: „Kdybyste měl rüct, který informace o politice by byly dưležitíj, jakej typ informací je duiležitej a kterej naopak neni duiležitej. “

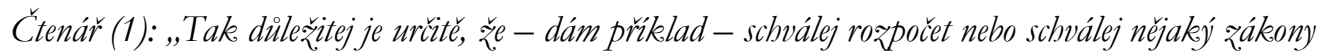
pro nás duiležitý, pro normálni lidi. Tak to si myslim, že je duiležity, to by se mèlo psát. Ale rozhodnè by se nemèlo psát, tadyble ̌̌e, já nevím kterýho toho, kluk spadl támble do kašny (syn primátora a poslance Pavla Béma, pozn. autor) a useklo mu to ruku a on najednou má nejlepšs pécí a ruku mu udèlaj novou. Já už nevím, kterej to byl, ruku mu udèlaj novou a hotovo. Tak to si myslím, že by se ani psát nemèlo."
\end{abstract}

Důvodem vyhýbání se vyprávění př́iběhů o výhodách politiků a jejich hodnocení může být to, že získávání různých výhod a služeb přes známé je vnímáno jako obvyklá praktika všech lidí, o které se obecně nemluví. Při publikování v médiích jsou výhody politiků najednou viditelné a tím je zdůrazněna disproporce mezi výhodami politiků a výhodami čtenářu Blesku. Nejde pak ani tak o hodnocení této praxe jako fakticky špatné, ale o nespokojenost s tím, že někdo jiný, zejména jsou-li na něj kladeny větší morální nároky, má více možností získat něco lepšího. Ostatně situaci, kdy někdo získá neočekávané výhody, označovali čtenáři jako „politickou“ záležitost. Tak jedna ze čtenářek hodnotila pátrání po pohřešovaném dítěti. Vysoká pozornost, kterou média i policie věnovala pátrání po tomto dítěti, byla podle čtenářky dána zámožností jeho otce, který si byl schopen opatřit politickou výhodu v podobě pro běžného člověka nedostupných výdajů z veřejných zdrojů.

Moderátorka: „To je pravda, o tom se psalo hodně, o Aničce (Janotové, pozn. autor). “

Čnárka (5): „Na jednu stranu jsem si ríkeala, proč se děje takovýble. Chápu, že je to tragédie, ale nikedy si nepamatuju, že by se kvioli tomu dèly takový véci. Spiš mi prijde, že tatínek byl, nebo je, nákej váženej podnikatel, bohatej, movitej. Tak proto se dèjou takovýble politicky.."

Moderátorka: "O tom psalo daleko vic."

Ctenárka (5): „Daleko víc."

Moderátorka: „O stejnè vlastně broznejch věcech. “

Ċtenárka (5): „Presně tak. A tèch policajtù kolik do toho bylo nasazeno, hasiču, psü, kolik to muselo stát strašnè moc peněz: A zaplati to dañový poplatnici. Nepamatuju si, nikedy si prostě nepamatuju, že by po nákym ditéti se takble jó hodně pátralo."

\title{
8. Ochrana soukromého: Práce jako každá jiná a já na jejich místě
}

$\mathrm{Na}$ rozdíl od korupce, která intuitivně patři do oblasti veřejného, osobní a rodinný život v sobě a priori obsahuje právo na soukromí a s tím spojený nárok na ochranu před zveřejňováním. U politiků je možné argumentovat ve prospěch oslabení tohoto práva kvưli možnému vlivu soukromých záležitostí na výkon veřejné funkce, jak tomu bylo u korupce. Požadavek na zveřejnění či nezveřejnění informace ze soukromého života politiků tak závisí na použitém argumentu, který konkrétní jednání konkrétního politika spojuje, nebo naopak nespojuje s jeho výkonem veřejné funkce.

Jednu ze skupin argumentů ve prospěch ochrany soukromého života politiků je možné označit slovy „politika je povolání jako každé jiné“. Tyto argumenty často vychází z projekce vlastního života čtenářu do situace politika a s tím spojenými představami, jak by se oni sami cítili $\mathrm{v}$ př́padě zveřejňování informací ze soukromého života. Společensky akceptovatelné excesy v soukromém životě jsou tak podle čtenářů pro výkon veřejné funkce nepodstatné, dokud není u konkrétního politika prokázán jejich prrímý dopad na jednání ve veřejné funkci. Rovněž nejsou nutně indikátorem toho, jak politik bude veřejnou funkci vykonávat. Je to obdobná situace jako 
při výkonu běžného povolání, kdy poklesky soukromého života, neovlivňují-li bezprostředně pracovní výkon, nemohou být zahrnuty do pracovního hodnocení.

Ctenár (1): „Prostě myslím, že to nemưže žádnej novinár odhadnout jenom z.toho, jestli vede

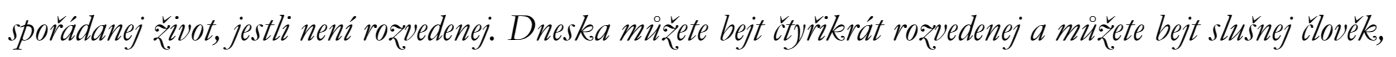
to preci se nedá takble brát. (...) Jestli takble se po nocích někede toulá, to bych rozhodně neaveréginoval, to je jeji osobni problém. Pokud ráno prìjde do práce a dèlá to, co má dèlat, tak proč ne. (...) To si myslím, že je jejich rivivot. Se rükáa, nebo jsem to nékede četl dokonce, že politik by nám mèl jút prǐkladem, že by se nemèl rozuádét, nemèl by mit milenky. Já si myslim, že to je ted' jedno, jestli je to chlap nebo ženská, jestli má milenky nebo milence. Myslim si, že je to čistě každýho věc a jestli je politite nebo čišník nebo novinár, mi prijde, ̌̌e je to úplnè jedno, a myslim si, že toblecto je jejich soukromí, a já bych tobleto nepsal, jestli má

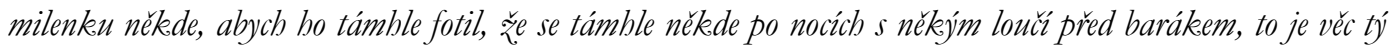
man ̌̌elky jeho a možná tý milenky, těch trech, a netabal bych to do médii. “

Druhou skupinu argumentů a zároveň druhým způsobem projekce do osoby politika je možné označit čtenáři používanou rétorickou figuru ,já na jejich místě“. V této figuře představují sami sebe v situaci politika a argumentují hypotetickým pocitem práva na ochranu soukromí, který by jako politici měli. Projevují lidské porozumění pro nepř́jemnou situaci, které je politik vystaven při zveřejňování těch informací ze svého osobního a rodinného života, jejichž publicitu si nepřeje. Tento argument je ostatně platný nejen pro politiky, ale i pro další veřejně známé osoby.

Ctenár (1): „Protože to beru jako zásah do rodiny, do soukromí. Já vím, že to taky o tom člověku nèco napovidá, ale nevím... Já se tedkea chci vžit do tý situace, kdybych já byl (politik, pozn. autor), kdyby se mi nékedo štoural, kedyžjá budu dèlat jakonkoliv práci a nèkedo se mi bude štourat, jestli s maň̌ellkou, jakejsme na tom, nebo to, to bych, to mi vadí."

Moderátorka: „Jak je to se Zounarem (herec, moderátor zábauných poradiu, pozn. autor)? Tam to vadí? Proč to intimni? "

Ctenárka (9): „Tak prece jenom je to taky clověk. Sice... je to známá osobnost, ale taky by mèl mít náký svoje soukromí. Mè by se asi taky jako nelibilo, kdyby o mně psal nèkedo, že sem byla na rande s tímblestim a támblestim a že jsme mèli $k$ večerì todleto a támbleto. Já to vidím u nás v práci nebo na vesnici. Tam nám stojí prè barákem auto a v tu ránu u气̌prostěs tím člověkem něco máte, a už prostě jedou takový ty pomluvy, žejo."

Skupina argumentů „já na jeho místě“ má zároveň svou stinnou stránku. Umožňuje čtenářum vyjádřit lidské pochopení pro zneužití veřejné funkce. Čtenáři si představují, že kdyby oni sami byli vystaveni nabídce úplatku nebo nějaké výhody stejně jako politici, také by neodolali.

Moderátor: „Kdybyste si mèl vybirat politiky, kteř̀ nám budou vládnout, nebo lidi, z kterých udèlat politika, aby nám vládli ... tak máme trébas ne bě̌žnýho politika, ale normální lidi a rékneme si, že něketerý z nich vybereme, aby nám vládli. Podle čeho je vybrat?"

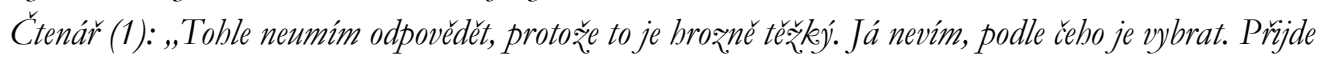
mi, že ... kedyž to rekenu blbě ... ono kdybych tam byl já ve vládé a mél jsem tu pröležitost krást, tak to budu asi dèlat taky. Řeknu to na rovinu. A myslim si, še to bude dèlat devadesát devèt procent lidí tohodle národa. V̌̀ech národü, to neni jenom v Čechách, myslim si, že to bude všude."

\section{Přezkum soukromí: Veřejná známost versus reprezentativnost}

Práci politiků je však také možné chápat jako specifické zaměstnání, se kterým je spojeno větší právo veřejnosti na přezkum soukromí, než by tomu bylo v př́padě jiného zaměstnání. Podle některých čtenářu může být osobní a rodinný život politika dưležitým indikátorem, který mưže 
pomoci poznat, jak politik bude vykonávat veřejnou funkci. Špatně vedený osobní život vypovídá o nepř́liš dobrém charakteru politika a varuje před budoucím zneužitím jeho politické moci. V této argumentační linii čtenáři často zdůrazňují svou politickou identitu - roli voliče, který potřebuje všechny dostupné informace $\mathrm{k}$ tomu, aby mohl udělat správné politické rozhodnutí.

Moderátor: „Kdybych volil mezi dvěma politikama, k. ̌̌emu potřebuju védět (...) řm se vonèj?"

Čtenár (4): „Protožẹ si o nèm udèlám i jinnou image. Potřebuju o tom člověku vědèt ne jenom, kolike má penèz, ale jak se chová ve společnosti. Když milionár Babiš puijde do společnosti a bude oblě̀enej jako buran, tak rekenu, no sice je to politik, ale jak bude vypadat? V ždyt' on si val úplné jinou kravatu k. tomu obleku, než by mèl mit, já o ném chci vèdèt i jiný véci, protože já ho neznám toho clověkea vỉbec. Já ho znám jenom, vím, jak vypadá, vím, že je bohatej člověk, vim, z čeho zbohatl, že kupuje podíly v bankách a v Rusku riizný naftový. Tak:že ted'ko já o tom člověku, pokud' o nèm chci rozhodovat tím, že si ho zuolím, nebo nezvolím, tak o nèm chci védèt víc. Ne jenom, jak se jmenuje. A právè, jestli se tam, jestli v Blesku nebo v

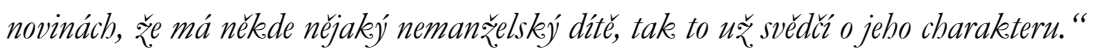

Jiným argumentem, který oslabuje ochranu soukromí, je konstatování „politici jsou veřejně známi“. Zdá se, že samotný fakt veřejné známosti je pro čtenáře dostatečným důvodem pro oprávněnost zveřejňování řady informací soukromého charakteru, respektive dostatečným důvodem pro to, aby tuto mediální praxi nezpochybňovali. Zveřejňování soukromí politiků prezentují jako daň za veřejnou známost a popularitu, stejně jako je tomu u celebrit showbusinessu. Zároveň je podle nich rolí právě Blesku jakožto bulvárního tisku poskytovat veřejnosti takové informace o politicích, které, ač pro výkon veřejné funkce mohou být relevantní, jsou seriózním tiskem opomíjeny: o chování v nejrůznějších životních situacích, o jejich vzhledu, stylu, oblékání, vystupování a osobnostních nedostatcích.

Ċtenár (4): „To jde ruku v ruce právě s politiky. Politik je veréjně známej, v televiz̨i, v novinách. Tak musite psát nejenom o tom, pro koho hlasoval, ale jak ř́kám, bulvár, tam lidi musej védèt, jakou má rád

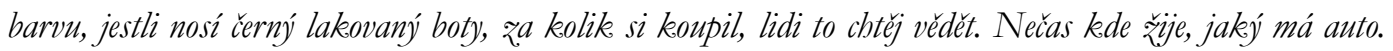
Ten človék ně̌ije izolovanej. A právé proto ten Blesk a AHA jsou noviny, který todle rozkerývaj, a ty lidi si to prè̌tou."

Moderátor: „A proč si myslite, že je pro lidi zajímavý, že Topolánek byl na dovolené?"

Ċtenár (2): „Samožrejmè, je to zásah do soukromí, protože to je, byl to, známá osobnost, takžze lidi to holt budou sledovat, je to jasný (smich), ̌̌e ho budou sledovat. Mě to tak moc nebere, ale ty jiný lidi prostě to (zajimá, pozn. autora)."

Politici tuto svou známost podle čtenářù sami podporují. Stejně jako celebrity se snaží zvýšit svou známost a popularitu tím, že poskytují informace o svém soukromí. Článek „Paroubek: Ráno pláž, večer bazén... Exšéf ČSSD se vrátil z řecké pohádky do české ,pastoušky“" (Blesk 2010c), čtenář hodnotí jako Paroubkovu sebeprezentaci v roli populární celebrity, která je pro politika nedůstojná.

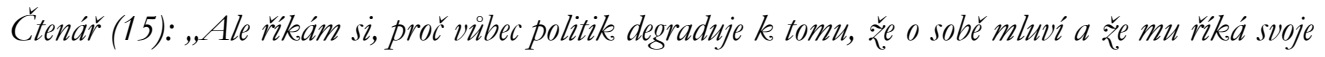
intimni věci - z rodiny, kede byl, co délal, že tam mèli bazén, co jedl a tak dále. Že už to jsou ... že jak o tom mluvim, mi prĭjde jako bulvár, že je to člověke, kterej je na nákym postu a ̌̌e se chová jak náká celebrita, dejme tomu Agáta Hanychová, chodí do klubio udèlá tam dycky ñákej skandál jen proto, aby byla vidèt. A tady na drubou stranu oni (Blesk, pozn. autora) nemaj asi v tu chvíli co psát nebo chtě̀j o nèm nèco napsat nebo, já nevím, jestli si to zaplatil. Aby mèl ... pozitivni oblasy od čtenárüu, což. nikedy nevite. Ale já si svébo soukromi brozně vážim a roz̧odně bych nechtèl, aby ñákej redaktor o mně psal, co jsem dèlal na svý dovolený. Ani že by mè chtèli špehovat a tak. podobnè." 
I přes veřejnou známost by podle čtenářů měla existovat určitá meze ochrany soukromí politiků. Jednou ze symbolických hranic mezi veřejným a soukromým mohou být zavřené dveře domova, který je základním místem ochrany soukromí člověka před zraky okolních lidí. Ve svém obydlí se lidé mohou dopouštět i neobvyklého jednání, které, není-li jednáním nelegálním, má být chráněno před zásahem zvenčí. Právo politika na soukromí ve svém obydlí je silnější než právo veřejnosti na přezkum vyplývající z jeho veřejné funkce.

Ctenár (4): „Politik, nebo sportovec, špičkovej sportovec, špičkovej budebnik nebo špičkovej dirigent,

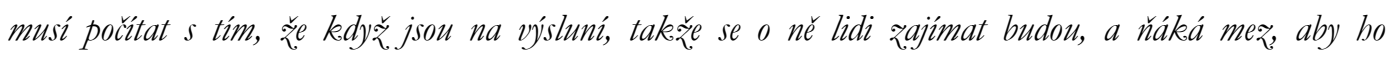
nevotravovali, to neni argument. Přjjde domü, zavre za sebou a tam at'si délá co chce, at' je sadomaso, doma jo, to nikoho nezajimá. Ale kdy žpude a navstiví nočni klub a je tam sadomaso, tak se nemuiže divit, žes v tèch novinách lidi tam vidéj, jak. tam klepe na to, a udèlaj si vo tom úsudek. "

I když politici i celebrity mají společnou svou veřejnou známost, jsou tyto dvě skupiny v očích čtenářů přeci jen rozdílné. Celebrity zpravidla reprezentují samy sebe. V tomto smyslu je veškeré jejich jednání povolené, protože je vázané pouze na tu kterou celebritu a její atributy (kterými jsou třeba serióznost Karla Gotta a bláznivost Ivety Bartošové). U politiků je stále př́tomná vazba na veřejnou funkci, prostřednictvím které na ně čtenáři kladou nárok na reprezentativní vzhled a vystupování ${ }^{11}$ jak ve veřejném, tak i v soukromém životě. U zpěvačky Ivety Bartošové čtenáři nekladou požadavky na to, jak by se měla ve svém osobním životě chovat, a její nevhodné chování vede pouze k jejímu označení jako bláznivé. V případě političky Karolíny Peake jsou kladeny požadavky na její činy v soukromém životě i v situaci, kdy to nemusí být prímý vliv na její jednání ve veřejné funkci. I když čtenář zdůrazňuje, že soukromý život ( $s$ kým spỉ) nemá vliv na výkon veřejné funkce, zobrazování tohoto života podle něj tuto veřejnou funkci znevažuje, ubírá jí na důstojnosti. A v tomto smyslu by i politici měli svůj osobní život kontrolovat a nezveřejňovat, držet za uzavřenými dveřmi obydlí, aby svým chováním nenarušovali reprezentativnost veřejné funkce.

Čtenár (1): „Myslím si, že ta Peake v politice by mèla mit nèjakou svoji duistojnost, kedyž to blbě réknu. Nebo ti novinári by k ni mèli mit néjakou určitou, nèjakej určitej odstup a mèli by o ni psát seriózní véci, a ne o ni psát, s kým spi a jaký má črslo podprsenky. Kdežto o tý Bartošový, ta si to suým zpơisobem udélala sama, protože s tim jak vystupuje a jak se chová. To zas o jiný zpèvačce nepišou, jiná zpèvačkea asi neni natolik bloupá, aby tobleto dovolila, nebo takble se chovala."

I přes provázanost mezi výkonem veřejné funkce a osobním či rodinným životem se zdá, že čtenáři rozlišují mezi veřejnou a soukromou sférou a mezi různými informacemi ze soukromé sféry. Z pohledu čtenářu negativní informace o osobním životě politika nemusí být nutně diskvalifikující pro hodnocení výkonu veřejné funkce. To, že si Paroubek našel novou, mladou manželku, hodnotí jiný čtenář jako jeho slabost. Zároveň však zdůrazňuje jeho schopnosti v politice, které jsou podle něj důležitější než určité chování v osobním životě. Preferencí konkrétních osobností politiků a jejich programu zároveň čtenář zdůrazňuje své politické kompetence, nebot’ zakládá své rozhodování ve volbách na základě plnění volebního programu jakožto jasně politického kritéria.

Moderátor: „Co vám na jeho (Paroubkově, pozn. autora) chováni vadilo?"

Čtenár (14): „No právě že úplnè všecko. Mnè vadéj lidi, který po boku ñáký ženy dosáhnou úspèchu a

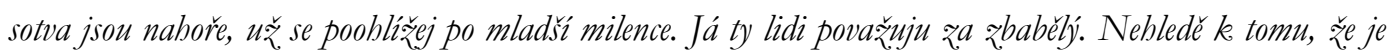
nepovažuju ani za brdiny. Protože kdy ž nékedo si myslí, že vypadá jako borec, tak já si myslim, že když

${ }^{11}$ Vzhled a vystupování politika je možné pojímat jako oprávněnou součást reprezentace voliče (srov. Brennan, Hamlin 2000). 
někedo potrebuje mladš a mladš ženu k tomu, aby mobl mit sex, tak to je ukáąka toho, jak mu slábne potence, a ne jakej je borec. Kdyby mèl tu potenci v porádku, ǔ̌ije si sex se svoji stejnè starou ženou, se

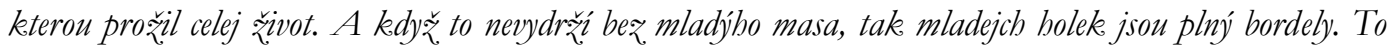
neni divod rozvracet rodinu."

Moderátor: „Je to třebas dĩvod, proč byste ho nevolil jako predsedu sociálni demokracie? Proč byste tam preferoval nèkoho jinýho, a nebo to neni zas tak duiležité?"

Ctenár (14): „Neni to duiležitý. Já mữu volit človêkea, o kterým si myslím, že je debil. Sociálni politiku dèlal, byt' já si o nèm mǐ̌u myslet, že je hovado. Kdyby tam byl, volil bych ho. (...) Já nejsem

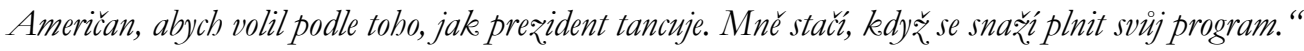

Záležitosti soukromého života, které jsou podle čtenářů obecně akceptovatelné pro mediální zveřejnění, jsou pozitivní a do určité míry oficiální významné životní události, jako je narození dítěte či dovolená. Oproti tomu by podle čtenářů měly raději zůstat skryté ty záležitosti soukromého života, které nějakým způsobem „dělají ostudu“. Zdálo by se, že nevhodné oblečení politika na dovolené patří a priori do soukromé oblasti a mělo by být osobní záležitostí politika, stejně jako je tomu u běžných lidí. ${ }^{12} \mathrm{~V}$ pohledu čtenářù však nevhodné oblečení i v soukromém životě degraduje reprezentativnost spojenou s veřejnou funkcí - príčemž na reprezentativnost kladou na tomto místě čtenáři velký důraz (srov. Blesk 2011). Na jednu stranu mají výhrady vůči vysokým př́ijmům a lepší životní úrovni politiků, zároveň však mají za to, že lepš́ životní úroveň i v soukromém životě je pro reprezentování země a tedy i samotných občanů nezbytná.

Čtenárka (8): „To jsem četla, Topolánka (výš́e zminèný clánek o Topolánkově dovolené, pozn. autor), ale mnè to prìjde ǔ̃... je to jeho soukromi, kam si jede, a mné docela vadí - na to, že to je takovejdle politik -, že se takovýdle věci jako rozebiraj až takle. Mnè to prijde ... nevím, jestli by se to mèlo prépirat až takble na verejnosti. Prece jenom je to nás politik, a nevím, jestli zrovna todle mu dèlá tu správnou vizitku. Jestli zrovna todleto Ceskou republiku reprezentuje, když se o nèm takble piše v novinách. Když si to prècteme my

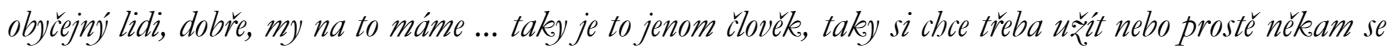
podivat. Ale pak vidéj poslanci a blavy státù, tak si réknou, co to je to zač, ta Česká republika? (Že tam maji, pozn. autora) takovýdlebo politika. (...)"

Moderátorka: „Kdybyste Vy to mèla posoudit podle toho, aby nás politici dobre reprezentovali, co by se o nich mèlo psát?"

Čtenárka (8): „O tom soukromi asi taky nèco. Když se jim narodí ditě nebo když si poř́déj novýho psa, nebo i tréba dovolená, kedyž se nékam jedou podivat. Ale právě né takový ty soukromý vèci. “

\section{Závěr}

Soudobá masová média předkládají široké veřejnosti nejen informace o oficiálních vystoupeních politiků při plnění povinností daných veřejnou funkcí, ale i o jejich činech z pozice soukromých osob, které by mohly, skutečně či domněle, výkon veřejné funkce ovlivnit. I když tradičně je nahlíženo na zveřejňování informací o osobním a soukromém životě politiků jako na odlákání pozornosti k politicky irelevantním informacím, je možné tyto informace interpretovat jako přibližení jinak nesrozumitelného světa politiky široké veřejnosti, která př́i porozumění politice vychází z vlastní zkušenosti založené na každodenním soukromém životě. Tento text se zaměřuje na argumenty, kterými členové veřejnosti kategorizují informace o soukromém životě politiků na ty, které by měly být $\mathrm{v}$ médiích zveřejňovány, a na ty, které nikoli. Jako představitelé veřejnosti

${ }^{12}$ I když i u běžných lidí bývá diskutováno, jakým způsobem na dovolené reprezentují Českou republiku (Blesk 2010d). 
figurovali v prezentovaném výzkumu pravidelní čtenáři nejčtenějšího českého deníku Blesk, kteří byli vybráni jako symboličtí zástupci masy vnímané coby protiklad elity.

Při obhajobě zveřejňování informací z politikova osobního života zdůrazňují čtenáři Blesku vliv politikova soukromého života na výkon veřejné funkce. $V$ první řadě mohou informace ze soukromého života sloužit jako indikátor morálního profilu a osobnosti politického kandidáta, tedy naznačují, jak se bude politický kandidát chovat po svém zvolení ve veřejné funkci. Př́padné nedostatky v soukromém životě ukazují, že s osobností politického kandidáta není něco v pořádku a svou veřejnou funkci nebude vykonávat v souladu se svými sliby či s očekáváním veřejnosti. Zveřejňování informací ze soukromého života může být také obhajováno jako nástroj odhalování toho, jak je svěřený politický úřad zneužíván pro získání nejrůznějších neoprávněných výhod v soukromém životě, jak jsou politici korumpováni. Současně je zveřejňování informací ze soukromého života obhajováno poukazem na status politiků jakožto veřejně známých osob srovnatelných s mediálními celebritami, které také těží ze své veřejné známosti a popularity a u kterých je publikování osobních informací obvyklé. Čtenáři také poukazují na to, že politici mohou sami účelově zveřejňovat některé informace ze svého rodinného života, aby si zajistili pozornost a osobní sympatie veřejnosti.

Argumentace proti zveřejňování informací z politikova soukromého života se opírá o srovnání práce politika s jinými zaměstnáními. Čtenáři, kteři takto argumentují, dávají práci politika principiálně na úroveň s prací v jakémkoli jiném zaměstnání. Stejně jako mají mít běžní lidé právo na ochranu soukromého života před zveřejňováním, mají také politici právo na širokou ochranu svého soukromí, nebot' i problematické jednání v soukromém životě nemusí mít žádný vliv na výkon veřejné funkce. Čtenáři zde vycházejí ze své vlastní životní zkušenosti, kdy tvrdí, že jejich soukromé prohřešky se nemusí projevit na jejich pracovním výkonu, a nemohou tak být zaměstnavatelem penalizováni. Výjimkou může být pouze situace, kdy ze strany politika dochází ke ztrátě kontroly nad oddělením soukromého života od veřejného - obdobně jako když běžný člověk kvưli své opilosti není schopen řádně vykonat své zaměstnání. Druhou možností je spáchání trestného činu, které jakožto překročení jasně daných norem má být vždy zveřejněno. Oproti tomu morální nebo módní prohřešky postrádají právní autoritu, na kterou by se mohli čtenáři odvolat. $V$ př́padě nevěry i v případě oblečení nošeného na dovolené záleží na životní zkušenosti a osobních preferencích čtenářu, zda jsou politikovi ochotni prŕpadné nedostatky prominout či mít pro ně porozumění. I přesto je však možné jako symbolickou hranici toho, co nemá být zveřejňováno, označit uzavřené dveře bytu, za kterými je tolerováno absolutní soukromí, byt' opět s výjimkou spáchání trestného činu.

Použitá výzkumná metoda spolu s počtem a výběrem respondentů představují limity pro možnosti zobecnění výsledků. Spíše než reprezentativní popis rozložení názorů v populaci, nabízí tento text sondu do způsobu uvažování těch př́jemců mediálních sdělení, u kterých je ve veřejném diskursu předpokládán, at’ již oprávněně, či nikoli, nevelký zájem o politiku a nízká politická participace. S ohledem na rozsah textu bylo možné raadu zajímavých souvisejících témat nanejvýše naznačit. Tento text tak může sloužit jako východisko pro další studie zaměřené na vztahy široké veřejnosti k politickému dění.

\section{Bibliografie}

Bailey, J. (2002): From Public to Private: The Development of the Concept of the ,Private', Social Research, roč. LXIX, č. 1, s. 15-31. 
Baum, M. A. (2002): Sex, Lies, and War: How Soft News Brings Foreign Policy to the Inattentive Public, The American Political Science Review, roč. XCVI, č. 1, s. 91-109.

Baum, M. A. (2003): Soft News and Political Knowledge: Evidence of Absence or Absence of Evidence? Political Communication, roč. XX, č. 2, s. 173-190. DOI: 10.1080/10584600390211181

Blesk. (2010a): Topolánkova famílie v Toskánsku: Kde na to bere? 25. 6. 2010, online verze (http://www.blesk.cz/clanek/zpravy-politika/138179/topolankova-familie-v-toskansku-kde-na-tobere.html), [cit. 10. 9. 2013].

Blesk. (2010b): Vzal bývalý senátor úplatek? Korupce po letech u soudu, Blesk, 20. 7. 2010.

Blesk. (2010c): Paroubek: Ráno pláž, večer bazén... Exšéf ČSSD se vrátil z řecké pohádky do české ,pastoušky'，5. 8. 2010, online verze (http://www.blesk.cz/clanek/zpravy-politika/140237/letopodle-paroubka-rano-plaz-vecer-bazen.html), [cit. 10. 9. 2013].

Blesk. (2010d): Nejhůře oblékaní turisté? Britové!, 7. 6. 2010, online verze (http://www.blesk.cz/clanek/radce-cestovani/137309/nejhure-oblekani-turiste-britove.html) , [cit. 10. 9. 2013].

Blesk. (2011): Lidový Nečas: Typicky česká dovolená, tvrdí odborníci, 2. 8. 2011. Online verze (http://www.blesk.cz/clanek/zpravy-politika/157050/lidovy-necas-typicky-ceska-dovolena-tvrdiodbornici.html), [cit. 10. 9. 2013].

Bobbio, N. (1989): Democracy and Dictatorship. The Nature and Limits of State Power, Minneapolis, University of Minnesota Press.

Boorstin, D. J. (1992): The Image: A Guide to Pseudo-Events in America, New York, Atheneum.

Brennan, G. - Hamlin, A. 2000. Democratic Devices and Desires, Oxford, New York, Cambridge University Press.

Corner, J. (2000): Mediated persona and political culture: Dimensions of structure and proces, European Journal of Cultural Studies, roč. III, č. 3, s. 386-402. DOI: 10.1177/136754940000300306

Černý, K. (2006): Sociologie a společnost: totalitární nástrahy, současné výzvy. Rozhovor s Miloslavem Petruskem. Sociologický časopis/Czech Sociological Review, roč. XLII, č. 5, s. 1063-1075.

Davidson, W. P. (1983): The Third-Person Effect in Communication, Public Opinion Quarterly, roč. 47, č. 1, s. 1-15. DOI: $10.1086 / 268763$

Davis, R. - Owen, D. M. (1998): New Media and American Politics, New York, Oxford, Oxford University Press.

Delli Carpini, M. X. (1996): Voters, Candidates, and Campaigns in the New Information Age: An Overview and Assessment, The International Journal of Press/Politics, roč. I, č. 4, s. 36-56. DOI: 10.1177/1081180X96001004005

Drake, P. - Higgins, M. (2006): I'm a celebrity, get me into politics: the political celebrity and the celebrity politician, in Holmes - Redmond. (eds.): Framing Celebrity: New Directions in Celebrity Culture, London, Routledge.

Farina, C. R. (2010): False Comfort and Impossible Promises: Uncertainty, Information Overload, and the Unitary Executive, University of Pennsylvania Journal of Constitutional Law, roč. XII, č. 2, s. 357424.

Frantová, V. (2013): Proč číst Blesk? Sociální teorie, 11. 11. 2013, online verze (http://socialniteorie.cz/proc-cist-blesk/).

Galtung, J. - Ruge, H. M. (1965): The Structure of Foreign News, Journal of Peace Research, roč. II, č. 1, s. 64-91.

Hall, S. (1999): Encoding, decoding, in: S. During (ed.): The Cultural Studies Reader, Routlege. 
idnes.cz. (2011): Vondráčková podle soudu nemá nárok na omluvu. 7. 3. 2011, online verze (http://revue.idnes.cz/vondrackova-podle-soudu-nema-narok-na-omluvu-fnp-

/lidicky.aspx?c=A110307_151227_lidicky_pad), [cit. 10. 9. 2013].

Jenks, C. (1998, ed.): Core Sociological Dichotomies, London, Sage.

Jungová, E. (2006): Obraz veřejnosti v tisku na př́kladu vládní krize: analýza MFDnes a Blesku, Praha, Univerzita Karlova, Fakulta sociálních věd UK.

Kabele, J. (2010): Heuristická strategie odborného studia společenských záležitostí, Sociologický časopis/Czech Sociological Review, roč. XLVI, č. 4, s. 593-618.

Kasl Kollmanová, D. (2012): Zveřejněné soukromí: utváření obrazu soukromého života politiků v médiích, Brno, Centrum pro studium demokracie a kultury (CDK).

Kuhn, R. (2007): The Public and the Private in Contemporary French Politics, French Cultural Studies, roč. IIXX, č. 2, s. 185-200. DOI: 10.1177/0957155807077996

Kvale, S. (2002): Dialogue as Oppression and Interview Research, Nordic Educational Research Association Conference Tallinn, Estonia, 7-9. 3. 2002, online verze (http://psy.au.dk/fileadmin/Psykologi/Forskning/Kvalitativ_metodeudvikling/NB32/dialogueoppt allinnNB.pdf), [cit. 10.9. 2013].

Langer, A. I. (2007): A Historical Exploration of the Personalisation of Politics in the Print Media: The British Prime Ministers (1945 - 1999), Parliamentary Affairs, roč. LX, č. 3, s. 371-387. DOI: $10.1093 / \mathrm{pa} / \mathrm{gsm} 028$

Langer, A. I. (2010): The Politization of Private Persona: Exceptional Leaders or the New Rule? The Case of the United Kingdom and the Blair Effect, The International Journal of Press/Politics, roč. XV, č. 1, s. 60-76. DOI: $10.1177 / 1940161209351003$

Lee, A. M. - Delli Carpini, M. X. (2010): News Consumption Revisited: Examining the Power of Habits in the 21st Century, 11th International Symposium on Online Journalism, Austin, TX, 23-24. 4. 2010, online verze (https://online.journalism.utexas.edu/2010/papers/LeeCarpini10.pdf), [cit. 10. 9. 2013].

Lumby, C. (1999): Gotcha: Life in a Tabloid World, St Leonards, Allen \& Unwin.

Macdonald, M. (2000): Rethinking Personalization in Current Affairs Journalism, in C. Sparks - J. Tulloch (eds.): Tabloid Tales: Global Debates over Media Standards, New York, Oxford, Rowman and Littlefield.

Marada, R. (2002): Masová média a proměny občanské veřejnosti. Revue pro média č. 3: Média a politika, s. $1-11$.

Meyrowitz, J. (2006): Všude a nikde: vliv elektronických médií na sociální chování, Praha, Karolinum.

Novák, A. (2003): Soudní přezkum správních rozhodnutí před obecnými a správními soudy, online verze (http://www.epravo.cz/top/clanky/soudni-prezkum-spravnich-rozhodnuti-pred-obecnymi-aspravnimi-soudy-21957.html), [cit. 10. 9. 2013].

Postman, N. (2010): Ubavit se k smrti. Veřejná komunikace ve věku zábavy, Praha, Mladá fronta.

Prior, M. (2003): Any Good News in Soft News? The Impact of Soft News Preference on Political Knowledge, Political Communication, roč. XX, č. 2, s. 149-171.

Prokop, D. (2005): Boj o média. Dějiny nového kritického myšlení o médiích. Praha: Karolinum.

Roberts, B. (2002): Biographical Research, Buckingham, Open University Press.

Street, J. (2004): Celebrity Politicians: Popular Culture and Political Representation, roč. IV, č. 4, s. 435-452.

Street, J. (2011): Mass Media, Politics, and Democracy, Houndmills: Palgrave Macmillan.

Thomas, D. R. (2006): A General Inductive Approach for Analyzing Qualitative Evaluation Data, American Journal of Evaluation, roč. XXVII, č. 2, s. 237-246. DOI: 10.1177/1098214005283748 
Van Zoonen, L. (1998): A day at the Zoo: Political Communication, Pigs and Popular Culture, Media Culture Society, roč. XX, č. 2, s. 183-200. DOI: 10.1177/016344398020002002

Van Zoonen, L. (2005): Entertaining the Citizen: When Politics and Popular Culture Converge, Lanham, MD, Rowman \& Littlefield Publishers.

Walsh, K. C. (2004): Talking about politics: informal groups and social identity in American life, Chicago, University of Chicago Press.

Weintraub, J. (1997): The Theory and Politics of the Public/Private Distinction, in: J. Weintraub. (ed.): Public and Private in Thought and Practice: Perspectives on a Grand Dichotomy, Chicago, University of Chicago Press.

Weiskel, C. T. (2005): From Sidesick to Sideshow - Celebrity, Entertainment, and the Politics of Distraction: Why Americans Are 'Sleepwalking Toward the End of the Earth', American Behavioral Scientist, roč. XLIX, č. 3, s. 393-409. DOI: 10.1177/0002764205280203

West, D. M. - Orman, J. (2003): Celebrity Politics, Upper Saddle River, Prentice Hall.

\section{Publish or keep hidden: How readers of the tabloid Blesk discuss the public and private lives of politicians}

\section{SUMMARY}

Despite the growing amount of available information on politics, the public obtains most of the information it requires for making political decisions from the mass media. The mass media offers a simplification of a complex world and often transfers policy to stories about its actors, meaning politicians. In the mass media, politicians appear in a wide variety of situations involving both their public and private lives.

Traditional opinion views the increasing focus of the mass media on the private lives of politicians, the so-called celebritization of politics, negatively. When the mass media focuses on the "infortainment" aspects of politics, politicians then become transformed into media stars with little political relevance. A newer revised view emphasizes the possible positive effects. As the public interprets politics on the basis of their everyday experience, official frameworks produced by political professionals are not so easy to understand. The personal stories of politicians can at least draw attention to politics.

This text addresses the issue of the disclosure of private information about politicians from the view of the recipients of mass media output. It focuses on the typical reader of the most popular Czech tabloid, Blesk, whose sociocultural characteristics are associated with signs of illiteracy, apolitical views, and opposition to the elite. This text presents an analysis of the arguments by which readers gauge the political relevance or irrelevance of mass media information about the public and private lives of politicians.

Data were provided by one focus group and 16 in-depth interviews with regular readers of Blesk. As the concepts of the public and private sphere were not a part of the ordinary language of the readers, the question indirectly became what the media should or should not publish. The analysis combines an inductive and a deductive approach, framed also by a heuristic approach, to the study of the observed issues. Interviews were coded by descriptive open codes and consequently by analytical axial codes. The codes were continually revised, refined, and interconnected.

An analytical model of the spheres of the public and the private was created during the analysis. It was based on the intersection of two dimensions of the concepts of public and private. In the first dimension, the public domain is defined by the presence of political power and thus coincides with the area of policy, while the private domain is defined as a complementary area outside of political power. 
The second dimension understands the public domain as an area of visibility that is accessible to review by the public and the private domain as an area hidden from it. Both dimensions are interconnected, because the dimension of political power constitutes normative demands on the possibility of public review. In contrast, the personal lives of ordinary people should be protected from review, as ordinary people are not holders of classical political power. The intersection of these dimensions creates four fields.

The first field is the sphere of political power, which exists in full view of the public. For readers, it is an idealized area of politics. The constructive efforts of political professionals are directed towards the benefit of society as a whole, and therefore there is no reason to hide anything from public view. An example of this field is approved law.

The second field is the sphere of political power that is hidden from public view. Politicians also actively conceal it, because it includes the abuse of political power for the private benefit of politicians or their associates - typically corruption. During the interviews, the readers were reluctant to talk much about such benefits although they knew of several stories about them. It seems that readers do not mind the abuse of public office so much as the great disproportion between the benefits achieved by politicians and the benefits that can be achieved by the readers in their ordinary lives. Political compromises, secret negotiations, and other realpolitik are also part of this second field. They do not correspond to the idealized notion of politics and readers evaluate them as being influenced by particular and private interests.

The third field is outside the sphere of political power but accessible to public review: the area of open access to the private lives of politicians. In this area, politicians are very close to having the status of media celebrities - both depend on popularity and their mass media image. In addition, both can actively release information about their family life to gain public attention and personal sympathy. In some readers' views, information from politicians' private lives can be a very important indicator of their performance of public functions, because they provide information about their personality. The poor management of personal lives can reflect badly on the very nature of politicians and warn of their potential abuse of political power. Readers also expect politicians to maintain certain minimum standards with respect to dress sense, for example, when on holiday.

The fourth field is outside the sphere of political power and both is and, according to the readers, should be hidden. The basic argument denies that public office should have an exceptional status and emphasizes the comparability of being a politician to the employment of ordinary people - public office is a job like any other. Unless one's private life has a demonstrably negative impact on the performance of one's public duties, private information should not be published. Readers often imagine themselves in the positions of politicians and admit that the disclosure of information about their private lives would not be pleasant. This argument, however, has its downside. It allows readers to express human understanding of the abuse of public office. Readers imagine that if they were themselves exposed to bribes as politicians are, they would also find them hard to resist.

As shown above, the unclear relationship between information about the public and private lives of politicians, on the one hand, and public office, on the other, gives readers the possibility of drawing different interpretations about the political relevance of the information. It seems that such interpretations are largely based on the particular life experiences of individual readers. Drunkenness or infidelity, for example, can thus be seen as indicators of a weak character or as a private matter for each person that should not be related to the evaluation of work performance. We finally suggest that research on political participation would be enriched by including the perspective of everyday life experiences of the general public.. 


\section{Př́loha 1: Charakteristika respondentů}

Respondenti hloubkových rozhovorů i diskusní skupiny byli rekrutováni na základě následujících kritérií:

- pravidelní čtenáŕi Blesku - kupují si jej alespoň 3x týdně (při ověřování respondentů se zeptat na hlavní články několika předchozích dnů);

- vzdělání: Bez maturity / středoškolské (preference vyučení bez maturity, mohou být i vyučení s maturitou a střední škola s maturitou, NE: VŠ), optimálně i někdo se základním vzděláním, bude-li schopen vyjádřit svůj názor;

- věk: 20 - 59 let;

- pohlaví: muži a ženy vyrovnaně;

- př́jem domácnosti: do 40 tis. Kč měsíčně;

- schopnost vyjádřit svůj názor či postoj (komunikativní při ověřovánî);různorodost respondentů.

Seznam respondentů:

\begin{tabular}{|c|c|c|c|c|c|c|}
\hline & Pohlaví & Vèk & Zamèstnání & $\begin{array}{l}\text { Frekvence } \\
\text { čteni Blesku }\end{array}$ & Co se v Blesku líbi ${ }^{13}$ & Co se v Blesku nelíbi \\
\hline \multirow{12}{*}{ 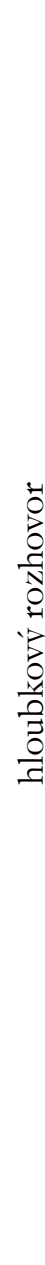 } & muž & 41 & číšník & $\begin{array}{l}\text { téměř } \\
\text { denně }\end{array}$ & sport & $\begin{array}{l}\text { reklama, př́liš } \\
\text { celebrit }\end{array}$ \\
\hline & žena & 23 & servírka & denně & společnost & politika \\
\hline & žena & 41 & $\begin{array}{l}\text { kontrolor } \\
\text { úklidu }\end{array}$ & denně & sport a drby & politika \\
\hline & muž & 52 & $\begin{array}{l}\text { ostraha } \\
\text { objektů }\end{array}$ & $\begin{array}{l}\text { téměř } \\
\text { denně }\end{array}$ & $\begin{array}{l}\text { sport a celé noviny, beru je s } \\
\text { nadhledem }\end{array}$ & čtu všechno \\
\hline & žena & 37 & skladnice & $\begin{array}{l}\text { téměř } \\
\text { denně }\end{array}$ & horoskopy, co se děje okolo & sport \\
\hline & muž & 40 & prodavač & denně & všechno & nic mi nevadí \\
\hline & muž & 43 & ostraha & $\begin{array}{l}\text { několikrát } \\
\text { do týdne }\end{array}$ & sport & móda \\
\hline & žena & 52 & servírka & $\begin{array}{l}\text { téměř } \\
\text { denně }\end{array}$ & drby & sport \\
\hline & muž & 25 & $\begin{array}{l}\text { account } \\
\text { executive } \\
\text { finance }\end{array}$ & $\begin{array}{l}\text { několikrát } \\
\text { do týdne }\end{array}$ & bulvár, sport & nic mě nenapadá \\
\hline & muž & 49 & vrchní číšník & $\begin{array}{l}\text { několikrát } \\
\text { do týdne }\end{array}$ & $\begin{array}{l}\text { zprávy, malé zprávy ve } \\
\text { sloupcích, dívka blesku }\end{array}$ & sport \\
\hline & žena & 19 & $\begin{array}{l}\text { prodavačka } \\
\text { bižuterie }\end{array}$ & $\begin{array}{l}\text { několikrát } \\
\text { do týdne }\end{array}$ & celebrity, bulvár, sport & vtipy na konci \\
\hline & žena & 55 & $\begin{array}{l}\text { OSVČ } \\
\text { nákup, } \\
\text { prodej, reality }\end{array}$ & denně & celebrity, bulvár, sport & sport \\
\hline
\end{tabular}

13 Tyto otázky byly respondentům položeny v průběhu rekrutování pracovníky komerční agentury kvůli ověrení jejich schopnosti komunikovat a pro potvrzení, že respondenti skutečně čtou Blesk. Spolu s dalšími charakteristikami respondentů byl záznam odpovědí na tyto otázky předán výzkumníkům, kteří z rekrutovaných respondentů vybírali účastníky výzkumu. 
Martin Volek: Soukromí politiků podle čtenářù Blesku

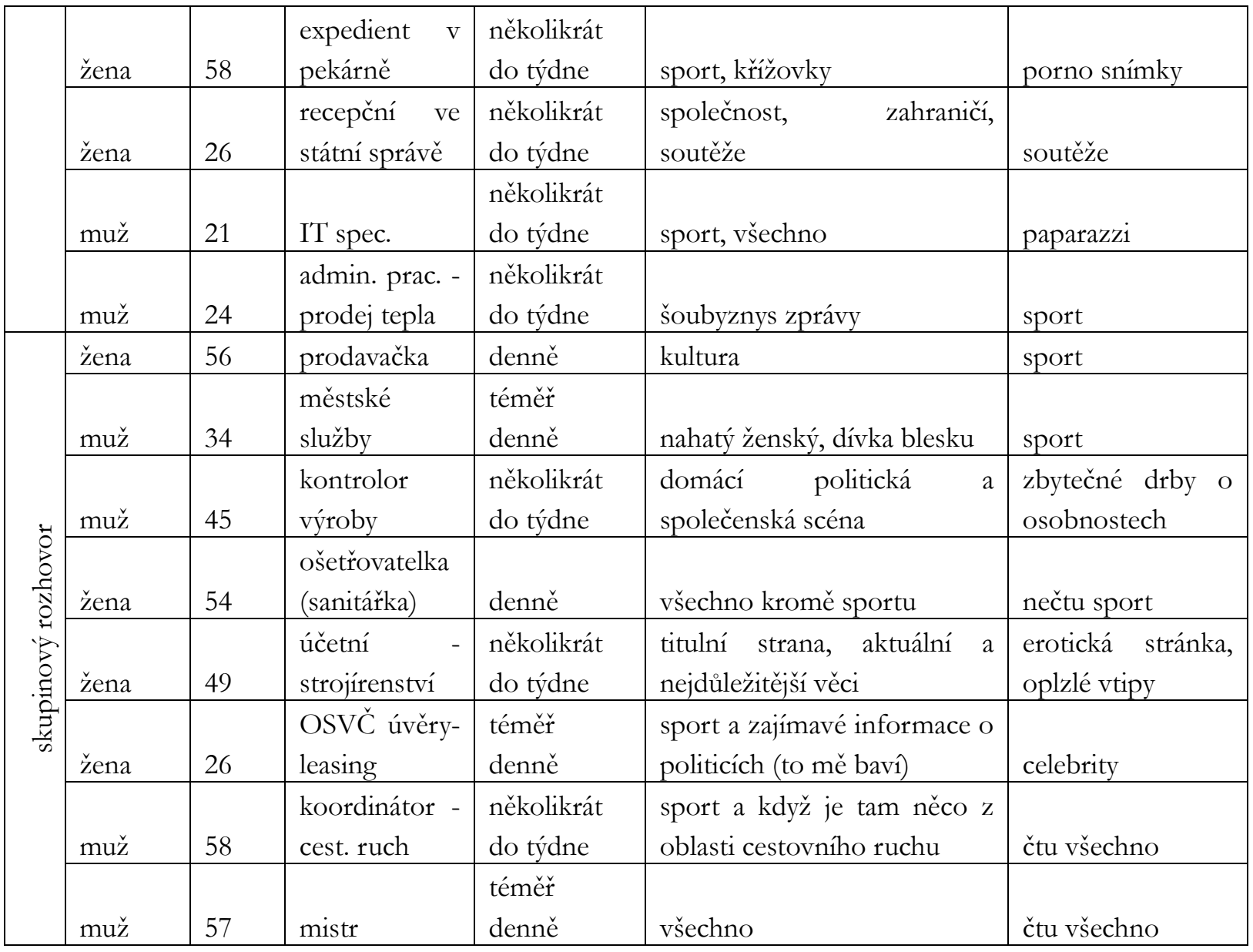

\section{Př́loha 2: Scénáŕ hloubkového rozhovoru}

\section{Úvod}

- Představení, Seznámení s pravidly rozhovoru.

- Přestavení respondenta.

Zájem o dèní kolem

- Co se děje? Co psali v novinách, ukazovali v televizi, rŕkali v rádiu? (cokoli - škola, práce, lokalita, zpěváci, herci, sport, politika) Co vás zaujalo? Co ještě?

- Odkud jste se o tom dozvěděla? Z jakých zdrojů?

Mediální chování

- Sledujete, co se děje? Jak často?

- Odkud se dozvídáte o tom, co se děje? (známí, média)

- Jaká média sledujete? (noviny, časopisy, televize, rádio, internet) Jaká dalš́i?

- Proč je sledujete? (zábava, informace)

- Jaká sledujete nejvíce? Proč?

- Které byste mi doporučili? Proč?

Blesk - stručné

- Jak často čtete Blesk?

- Co se vám na Blesku líbí? Co vás v Blesku vždy zaujme?

- Co v Blesku čtete jako první?

- Jak ho čtete? Od začátku do konce, nebo přeskakujete? 
- Je něco, co nečtete?

- Je něco, co se vám na Blesku nelíbí?

Blesk versus ostatni noviny

- Porovnat Blesk s několika ostatními novinami, které čtou, nebo s TV zprávami.

- Když porovnáte Blesk a Mladou Frontu / Lidové noviny / Hospodárské noviny / TV zprávy, jaký je mezi nimi rozdíl?

- Proč raději / také rádi čtete Blesk?

- Pro koho jsou Mladá Fronta / Lidové noviny / Hospodářské noviny?

Čteni Blesku - detailně

- Co vás nedávno v Blesku zaujalo? Jaký článek? Proč právě ten?

- O kom se v tom článku psalo? (Všimnout si, jak nazývají to, co čtou - drby / celebrity / informace)

- A něco ze sportu vás zaujalo? A něco z kultury? A něco z politiky?

Ctenípolitiki u

- Pokud si na nic z politiky nevzpomene, ukázat dnešní Blesk / vybrané články.

- Co se tam píše? Co vás na tom zaujalo? Co si o tom myslíte?

- Proč č́st takovou věc?

- Který z těch článků je nejzábavnější / nejzajímavější? Proč?

- Který z těch článků je nejdůležitějšś? Proč?

Co je veréjné

- Připomenout nějakou informaci o osobním životě politiků, která zazněla a která nesouvisí $\mathrm{s}$ politikou (typu Paroubek křtí dceru).

- Co vás na této zprávě zaujalo? $\mathrm{K}$ čemu je dobré tohle vědět?

Poù̃ití informaci pro volebni chování

- Chodíte k volbám? Proč ano/ne?

- Koho jste volilil? Proč právě toho?

- Podle čeho jste ho vybírali? (Jak vypadá (oblečení, úprava zevnějšku), jak se chová (veřejně i soukromě), jak se chová k dětem, zda pije, zda podvádí manžela či manželku, jaký má majetek, ...)

- Co o něm psali v Blesku?

- Jaké informace vám o něm v Blesku chyběly?

- Byly tam nějaké informace navíc? Informace, které jste nepotřebovali?

- Kdyby Iveta Bartošová (nebo jiná celebrita zmiňovaná v diskusi) kandidovala, volili byste ji? Proč?

- Jaké informace o ní byste ještě potřebovali?

Pravidla pro zuerejñováni (fakultativnè)

- Představte si, že bychom nyní mohli stanovit pravidla, které informace o politicích by měly být a které by neměly být zveřejňovány.

- Jak byste tato pravidla nastavili? Co zveřejňovat? Proč? Které informace nezveřejňovat? Proč?

- Jsou nějaké informace z osobního života politiků, které by zveřejňovány být neměly? Které jsou jejich osobní a soukromou záležitostí? Které informace by to byly? Proč?

- Jak byste stanovili hranici mezi tím, co zveřejňovat, a co už ne? Co má čtenář právo vědět, a co ne?

- Splňuje v tomto Blesk vaše představy? Dozvídáte se v něm o politicích to, co chcete?

Závèr

- Shrnout a nabídnout vyjádření. 
- Poslední možnost něco dodat (Co nejdůležitějš́ího z našeho rozhovoru bych si měla zapamatovat?). 